\title{
Exit from the Roundabout
}

\section{Lucia Nardo}

He tells me he cried all night. Again. The words press me into the impossible position of trying to reach my teenage son. My heart stretches across the divide but I never quite get to him. He stands alone on a precipice staring into the yawning blackness that is ready to swallow him.

I put my hand on his shoulder, 'Sweetie-' He shoves me away, white with rage. 'Piss off!' He slams his bedroom door, forcing a gust of air into my face. It reeks of long nights of foul breath and weeks of unwashed clothing. Music pumps up. I lean against the door that separates us. Behind it, he is lost in an unmapped world. Territory I cannot help him navigate.

At school, his quick wit and razor sharp observations doom him to walk a thin line between engagement and expulsion. I spend his secondary years waiting for the phone to ring, for the inevitable call to account.

It comes.

'Usually he's just mischievous, however, there's been an incident,' the Principal says. A teacher slammed up against the lockers; punches thrown, rage ignited.

When the call ends, my heart reverberates louder than the music from his room. I'm sure he hears nothing but what is going on in his head.

The gate to the psychiatrist's home-based office makes a shrill screech as my son pushes it. The sound drills through my temples.The consulting room is permeated with a quiet assurance of understanding. My son curls his length into a question mark at one end of the plush sofa. I sit at the other end, cataloguing mistakes I'd made in raising him that he should be so unhappy, so disconnected, as to end up here. 
The psychiatrist, a tall, greying man with a gentle manner, asks questions in even tones, scratching notes in fountain pen as he gathers childhood and medical history.

My son's eyes fix on the world outside the window. The knot in my stomach tightens in the drawn-out pauses before every response he makes throughout the fifty-minute hour.

We leave without any answers, just a brief, 'Same time next week.'

He races to the car, all angles and long limbs that poke from his too short, too tight uniform blazer. He rips away his tie, pocketing it; burying the constraints that he cannot name and cannot control.

I ache for his pain to stop. 'The doctor seems nice.' My high pitched voice betrays my anxiety. 'Did you like him?'

He grunts and waits for me to unlock the car; thuds into the front seat, mute.

The drive home is peppered with my bland observations of the world around us, aiming for neutral ground. Each comment is met with a shrug.

I sense the small hand that once only wanted to hold mine, slipping away forever. For the first time in sixteen years, I feel I have lost my child. I bite my lip until it goes numb. 'Can we stop at Maccas?' he asks without looking at me.

We find a McDonald's, where everything is predictable. Over burgers and chips, we spend half an hour being ordinary.

He keeps his bedroom door barricaded with an orange traffic cone. Routine is no longer part of life's rhythm in the months that follow. I mentally script out the start of every conversation so that it won't end in violent frustration and his sharp words driving deep into my flesh. Grief shreds my insides before it segues to anger-anger at him-until shame consumes me.

Everything ends the same way it starts—unfinished. I ride out his unpredictable moods, always on high alert.

It feels like I haven't breathed out for years.

Months of regular sessions with the psychiatrist and one day, I'm asked to wait outside the consulting room during future appointments. I hear the dividing click of the door closing behind me as I go back to the waiting area.

Muffled voices hum from the room then a burst of laughter: my son's. Not a frenzied laugh; a deep throaty one. A normal laugh. 
My shoulders relax. Behind that door, he must feel safe.

Wisps of blue break through clouds in the spring sky as we make our way to an early appointment. I am not just the driver this day; the doctor wants me in the session.

The gate's familiar squeak has become a reassuring anchor. We wait on the porch for the buzzer to be answered. A breeze carries the scent of jasmine. I locate the blossom-laden vine climbing a rough brick wall, clinging on for survival. Like we've been doing for months.

I muse on spring's recurring promise of renewal.

'I'd like to start him on Lithium,' the doctor says in a voice accustomed to spilling such news many times before. 'We need to start treatment for Bipolar Disorder.'

'What's that mean?' my son asks, suddenly attentive. The doctor elaborates on symptoms, brain chemistry, medications and blood tests. I try to absorb it all over the countless questions ricocheting inside my head.

My son has only one: 'Will I be normal?'

The Lithium creates persistent thirst and an anticonvulsant makes him sleep for two days straight when he first takes it. Each time I pass his door, I press my ear to it, listening for his breathing.

Eventually he emerges, disoriented, queasy but determined. He'll try anything for normal. His despair draws us into a world of agitation and volatility.

'Depression is often more anger than sadness in adolescents,' his doctor explains.

Sometimes he sleeps all day; sometimes awake for days. He doesn't take his medications at the right intervals. Pharmaceutical combinations are added and subtracted. Directions keep changing.

Between appointments, time crawls.

When he is old enough to drive, another layer of my protection is stripped away. I lie awake at night, eyes fixed on the ceiling, my muscles tense and ears straining. In the daytime, fatigue slows the world; my head is fuzzy with half finished dreams of crumbling roads and unknown destinations.

His moods settle enough for the doctor to organise a battery of psychological tests.

He does not get through the IQ questions because they just ask the same 
thing in different ways but his creativity tests at the level of a thirty-five year old. He decides to go back to study in the creative arts, doing well until he befriends a free-spirited fellow student.

'There's no such thing as Bipolar Disorder', she tells him. 'You're an Indigo Child. You don't need drugs.'

He insists she knows about life when he discards his medications.

It takes a few short weeks for his bedroom walls to become pasted with scrap-paper poems. At first, lyrical and insightful then as his handwriting disintegrates to a scrawl, the words become incoherent ranting.

Eyes shine, pupils dilate. He's got grand plans.

There is no place for reason in his no consequences world. I can only watch, gutted, as his judgment becomes impaired and impulsivity overtakes every aspect of his life. One day, he drives through a roundabout and repeatedly circles in dizzy spins until the world outside blurs and melds with his laughter. Can't find a way out. His girlfriend presses against the window, screams for him to stop. Later, ashen, she tells me about it. All he remembers is the owl he saw in his passenger seat; a hallucinated hitchhiker in an upswing world.

He is the only one surprised when the relationship ends.

Antipsychotic drugs bring his mood down through an exhausting period of initial side effects. He is heavy with the misery of living. His face is alabaster, eyes dart to every corner. His fear so palpable, it oozes from his pores and coats my skin. 'Ma, you have to put me somewhere.' He lifts his tee-shirt to reveal criss-cross cuts across his torso. Some scabbed; others oozing fresh blood.

My world spins and splinters into pieces I will never be able to reassemble. I don't have words. My mouth feels like it's filled with sawdust. I cradle his head and we sob together; me gulping for air, willing him not to shatter.

I pull him close, holding the fragile fragments that remain.

In a clinic, he follows a therapy regime, eats regular meals, has his sleep monitored. His room is devoid of anything personal, anything he could potentially use to hurt himself. A small room designed to constrain a personality that has grown too big.

We sit in the grounds under an evening summer sky the colour of roses; a day that should be for warm hearts.

'What's gonna happen to me when you die, Ma?' His words sting like ice on my skin. 'You'll be better before that.' I say, feigning confidence. 
His eyes shift away to an inaccessible future. 'I may as well die now.' The idea makes him restless, agitated, has to go.

'Don't forget to take your meds.' Impotence echoes in my words. Darkness gathers in the bright green of his eyes. He laughs; snorts irony. 'I didn't forget them, Ma. Still wound up here.'

Over time, triggers become identifiable: tiredness, stress, rapid lifechanges, relationships starting, relationships ending, a bad dream, a good dream, winter, early spring; the list is endless. Life. Life triggers the mood swings. In highs, sleep goes first; every pinch of life has to be savoured. Creativity strikes with energy sapping force. His world becomes one of energetic imaginings hatched in bursts of inspiration and too much laughter.

No-one is allowed to get in his way. Friendships are ruined; forgiveness withheld. On the downswing, his moods are as black as the ashes of the bridges he has burned. The act of breathing is an effort. He's burdened by his thoughts, convinced he's in permanent darkness.

I'm a spectator to the mood cycles; the monitor of medications. It's the only useful thing I can do until gradually, the time between episodes widens more and more.

Stability returns. And it begins to linger. 'Think I'm on track,' he says, wanting to believe it. He knows there are few stretches of straight road but he still hopes for an exit from the roundabout.

'Got a job interview, Ma. They probably won't hire me.' His confidence has ground to powder over the years. In the days leading to the interview, he calls every day, expounding an anxious breathless list of the reasons he will fail. The night before, he phones at hourly intervals until it hits two am and I fall into exhausted sleep, face damp with tears, all hope washed out of me.

In the morning, I steel myself as the interview time passes. I fumble the phone, answering his call in a brittle voice, anticipating his distress.

'I got the job!' He pours out the details then pauses, 'Ma, why are you crying?'

The yearly wall calendar has changed ten times since his first walk to the psychiatrist's door. He has morphed from boy to man, built an independent life shaped through music, friends and work. He can plot a deft course around life's pot holes.

Despite that, my anxiety for him is always a blink away. I hover around 
the edges of his life; looking for any sign of an episode. Up or down, the direction will not matter.

It's a road trip we take together.

He visits. I wrap my arms around his towering frame, the top of my head fits neatly under his chin. He returns the hug tolerantly, patting my back, his heart drumming restlessly under my ear. 'Gotta go. Got things to do.' Unwilling, I release him. 'Did you take your meds?' He rolls his eyes and laughs. 'Don't worry, Ma! It's all good.' Maybe now it is. I exhale a long-held breath; release my grip on the steering wheel. He has seen an exit up ahead and, in his eyes, there are fragments of hope. 